\title{
The association analysis of TLR2 and TLR4 gene with tuberculosis in the Tibetan Chinese population
}

\author{
Xin Xue ${ }^{1,2}$, Yi Qiu ${ }^{3}$, Dong Jiang ${ }^{4}$, Tianbo Jinn ${ }^{5,6}$, Mengdan Yan ${ }^{5}$, Xikang Zhu ${ }^{6}$ and \\ Yonglie $\mathrm{Chu}^{1}$ \\ ${ }^{1}$ Department of Pathogen Biology and Immunology, Xi'an Jiaotong University Health Science Center, Xi'an 710061, China \\ ${ }^{2}$ The Fourth Internal Medicine, Xi'an Chest Hospital, Xi'an TB and Thoracic Tumor Hospital, Xi'an 710100, China \\ ${ }^{3}$ The Second Internal Medicine, Xi'an Chest Hospital, Xi'an TB and Thoracic Tumor Hospital, Xi'an 710100, China \\ ${ }^{4}$ Inner Mongolia Medical University, Hohhot 010010, China \\ ${ }^{5}$ Key Laboratory of Resource Biology and Biotechnology in Western China (Northwest University), Ministry of Education, \\ School of Life Sciences, Northwest University, Xi'an 710069, China \\ ${ }^{6}$ School of Medicine, Xizang Minzu University, Xianyang 712082, China \\ Correspondence to: Yonglie Chu, email: yongliechujiaoda@163.com \\ Keywords: PTB; SNP; case-control study; Tibetan Chinese population
}

Received: March 29, $2017 \quad$ Accepted: August 06, $2017 \quad$ Published: December 06, 2017

Copyright: Xue et al. This is an open-access article distributed under the terms of the Creative Commons Attribution License 3.0 (CC BY 3.0), which permits unrestricted use, distribution, and reproduction in any medium, provided the original author and source are credited.

\section{ABSTRACT}

Background: The present study was undertaken to explore the relationship of Toll-like receptor (TLR) 2, TLR4 genes polymorphisms with Pulmonary tuberculosis (PTB) risk in a sample of Chinese population.

Methods: For this study, we recruited 467 subjects with PTB and 504 healthy subjects from a Tibetan population living in near or in Xi'an, China. Association analyses of single-nucleotide polymorphisms (SNPS) in TLR2 and TLR4 were performed with SPSS Statistics (version 17.0), SNPStats, Haploview (version 4.2), and SHEsis software.

Results: The research results that is association analysis of pulmonary tuberculosis show there are two increased-risk SNPs (rs7696323, OR $=1.32,95 \% \mathrm{CI}$ $=1.08-1.62, P=0.007 ;$ rs12377632, $O R=1.30,95 \% C I=1.09-1.55, P=0.004)$ and three decreased-risk SNPs (rs3804099, $O R=0.64,95 \% C I=0.52-0.79, P=1.95^{*} 10^{-5}$; rs3804100, OR=0.67, 95\%CI $=0.54-0.82, P=0.0001 ;$ rs11536889, $\mathrm{OR}=0.54,95 \% \mathrm{CI}$ $\left.=0.42-0.69, P=9.14^{*} 10^{-7}\right)$.

Conclusions: We found that two SNPs are associated with increased PTB risk and three SNPs decreased PTB risk in the Chinese Tibetan population. Our findings demonstrate an association between TLR2 and TLR4 polymorphisms and PTB.

\section{INTRODUCTION}

Pulmonary tuberculosis (PTB) is caused by Mycobacterium tuberculosis (M. tuberculosis) and is one of the leading causes of death worldwide. Since 1980, the PTB incidence and mortality rate have increased rapidly [1]. There are more than 9 million people with PTB, and more than 1.7 million people have died of PTB [2]. The incidence of PTB in Asian countries accounts for $60 \%$ of the worldwide total.
The number of PTB patients in China is the second largest in the world, and China is ranked on a list of 22 high-burden countries. Although M. tuberculosis has infected almost one-third of the population worldwide, only $10 \%$ of patients produce corresponding clinical symptoms during their lifetime [3], illustrating that additional factors may influence the incidence of disease among different individuals.

Previous studies have identified genes that confer disease susceptibility by regulating the immune response 
Table 1: Characteristics of PTB patients and control participants

\begin{tabular}{lccc}
\hline Variable & Case & Control & P \\
\hline Total & 467 & 503 & 0.508 \\
Age $($ Mean \pm SD) & $50.67 \pm 7.80$ & $50.34 \pm 7.74$ & 0.947 \\
Gender & & & \\
Female & 287 & 308 & 195 \\
$\quad$ Male & 180 & & \\
\hline
\end{tabular}

$\mathrm{p} \leq 0.05$ indicates statistical significance.

Table 2: Allele frequencies in cases and controls and odds ratio estimates for tuberculosis

\begin{tabular}{|c|c|c|c|c|c|c|c|c|c|c|c|c|}
\hline \multirow[t]{2}{*}{ SNP } & \multirow[t]{2}{*}{ Chromosome } & \multirow[t]{2}{*}{ Position } & \multirow[t]{2}{*}{ Band } & \multirow[t]{2}{*}{$\begin{array}{c}\text { Alleles } \\
\text { A/B }\end{array}$} & \multicolumn{2}{|c|}{$\begin{array}{l}\text { Major allelic } \\
\text { frequency }\end{array}$} & \multirow[t]{2}{*}{ Gene(s) } & \multirow[t]{2}{*}{$\begin{array}{c}\text { HWE } \\
P \text { value }\end{array}$} & \multirow[t]{2}{*}{ ORs } & \multicolumn{2}{|c|}{$95 \%$ CI } & \multirow[t]{2}{*}{$P$ value } \\
\hline & & & & & Case & control & & & & & & \\
\hline rs7696323 & 4 & 154605745 & $4 q 31.3$ & $\mathrm{~T} / \mathrm{C}$ & 0.281 & 0.719 & TLR2 & 0.704 & 1.32 & 1.08 & 1.62 & 0.007 \\
\hline rs1898830 & 4 & 154608453 & $4 q 31.3$ & $\mathrm{G} / \mathrm{A}$ & 0.469 & 0.531 & TLR2 & 0.031 & 1.05 & 0.88 & 1.26 & 0.609 \\
\hline rs3804099 & 4 & 154624656 & $4 q 31.3$ & $\mathrm{C} / \mathrm{T}$ & 0.226 & 0.774 & TLR2 & 0.534 & 0.64 & 0.52 & 0.79 & $1.95 \mathrm{E}-05^{*}$ \\
\hline rs 3804100 & 4 & 154625409 & $4 q 31.3$ & $\mathrm{C} / \mathrm{T}$ & 0.208 & 0.792 & TLR2 & 0.912 & 0.67 & 0.54 & 0.82 & $0.0001^{*}$ \\
\hline rs 10759932 & 9 & 120465144 & $9 q 33.1$ & $\mathrm{C} / \mathrm{T}$ & 0.378 & 0.622 & TLR4 & 0.001 & 1.37 & 1.13 & 1.67 & 0.001 \\
\hline rs 11536878 & 9 & 120471553 & $9 \mathrm{q} 33.1$ & $\mathrm{~A} / \mathrm{C}$ & 0.111 & 0.889 & TLR4 & 0.211 & 0.88 & 0.67 & 1.17 & 0.383 \\
\hline rs 12377632 & 9 & 120472730 & $9 \mathrm{q} 33.1$ & $\mathrm{~T} / \mathrm{C}$ & 0.489 & 0.511 & TLR4 & 1.000 & 1.30 & 1.09 & 1.55 & 0.004 \\
\hline rs11536889 & 9 & 120478131 & $9 \mathrm{q} 33.1$ & $\mathrm{C} / \mathrm{G}$ & 0.121 & 0.879 & TLR4 & 0.337 & 0.54 & 0.42 & 0.69 & $9.14 \mathrm{E}-07^{*}$ \\
\hline rs7873784 & 9 & 120478936 & $9 \mathrm{q} 33.1$ & $\mathrm{C} / \mathrm{G}$ & 0.088 & 0.912 & TLR4 & 1.000 & 0.96 & 0.70 & 1.31 & 0.778 \\
\hline
\end{tabular}

SNP single nucleotide polymorphism, OR odds ratio, $95 \%$ CI $95 \%$ confidence interval, $H W E$ Hardy-Weinberg equilibrium $p \leq 0.05$ indicates statistical significance.

${ }^{*} p$ value $\leq 0.05$ indicates Bonfferoni correction statistical significance.

$[4,5]$. A twin study found that PTB concordance in identical twins is 2-fold higher than that in non-identical twins [6]. Thus, we expect that identification of host genetic factors for PTB susceptibility might play a key role in PTB control worldwide. Genetic research has provided insight into tuberculosis, including the pathological and cytological bases of PTB. Several genes that influence PTB risk have been identified, including $V D R, M B L, T L R$, and $P 2 X 7$ et al. [7-9].

Among them, the polymorphism of TLR2 and TLR4 genes were considered to be the most closely related Tolllike receptor members of immunity and inflammation. The cooperation between TLR2 and TLR4 dependent signaling plays a crucial role in macrophage apoptosis triggered by PTB [10].

However, the association analysis between TLRs (especially TLR2 and TLR4) and PTB risk have been reported, few geneticists and cliniciansassess the association between TLR2, TLR4 and TB risk in the Tibetan Chinese population. By applying the case-control study method in epidemiology, to evaluate the association between common TLR2, TLR4 single nucleotide polymorphisms (SNPs) and the susceptibility of PTB in an Han Chinese population. We selected 4 tag SNPs of TLR2, 5 tag SNPs of TLR4 to perform a comprehensive association analysis with TB. Establishing our analysis to the risk of PTB loci, some evidences are provided to share hereditary susceptibility between PTB and three genes at 9 new loci in Chinese people.

\section{RESULTS}

Demographic and clinical features of the PTB and the control group are shown in Tables 1 and 2 showed allele frequencies and odd ratio estimates among the subjects in our case-control study. In Hardy-Weinberg balance verification, HWE $P$ value is the boundary value of the level of the candidate gene, thus rs 1898830 and rs10759932 were excluded. Determination of other seven SNPs in the control group show that they conform to the Weinberg Hardy equilibrium law HWE. There are two increased-risk SNPs (rs7696323, OR $=1.32,95 \% \mathrm{CI}=1.08$ $1.62, P=0.007 ; \mathrm{rs} 12377632, \mathrm{OR}=1.30,95 \% \mathrm{CI}=1.09-1.55$, $P=0.004$ ) and three decreased-risk SNPs (rs3804099, $\mathrm{OR}=0.64,95 \% \mathrm{CI}=0.52-0.79, P=1.95^{*} 10^{-5}$; rs 3804100 , $\mathrm{OR}=0.67,95 \% \mathrm{CI}=0.54-0.82, P=0.0001 ; \mathrm{rs} 11536889$, $\mathrm{OR}=0.54,95 \% \mathrm{CI}=0.42-0.69, P=9.14^{*} 10^{-7}$ ).

According to the genetic model analyses (Table 3), the T/T genotype ofrs6687758 increased 2.08-fold risk in 
Table 3: Logistic regression analysis of the association between the single-nucleotide polymorphisms and PTB

\begin{tabular}{|c|c|c|c|c|c|c|}
\hline \multirow{2}{*}{$\frac{\text { SNP ID }}{\text { rs7696323 }}$} & \multirow{2}{*}{$\frac{\text { Model }}{\text { dominant }}$} & \multirow{2}{*}{$\frac{\text { Genotype }}{\mathrm{C} / \mathrm{C}}$} & \multirow{2}{*}{$\frac{\text { OR }}{1.00}$} & \multicolumn{2}{|c|}{$95 \%$ CI } & \multirow{2}{*}{$\frac{P \text { value }}{0.063}$} \\
\hline & & & & & & \\
\hline & & $\mathrm{C} / \mathrm{T}-\mathrm{T} / \mathrm{T}$ & 1.27 & 0.99 & 1.64 & \\
\hline & recessive & $\mathrm{C} / \mathrm{C}-\mathrm{C} / \mathrm{T}$ & 1.00 & & & 0.005 \\
\hline & & $\mathrm{T} / \mathrm{T}$ & 2.08 & 1.24 & 3.47 & \\
\hline & genotype & $\mathrm{T} / \mathrm{T}$ & 2.19 & 1.30 & 3.71 & 0.003 \\
\hline & & $\mathrm{C} / \mathrm{T}$ & 1.15 & 0.88 & 1.50 & 0.305 \\
\hline & & $\mathrm{C} / \mathrm{C}$ & 1.00 & & & \\
\hline \multirow[t]{7}{*}{ rs1898830 } & dominant & $\mathrm{A} / \mathrm{A}$ & 1.00 & & & 0.360 \\
\hline & & $\mathrm{A} / \mathrm{G}-\mathrm{G} / \mathrm{G}$ & 0.88 & 0.66 & 1.16 & \\
\hline & recessive & $\mathrm{A} / \mathrm{A}-\mathrm{A} / \mathrm{G}$ & 1.00 & & & 0.056 \\
\hline & & $\mathrm{G} / \mathrm{G}$ & 1.36 & 0.99 & 1.85 & \\
\hline & genotype & $\mathrm{G} / \mathrm{G}$ & 1.16 & 0.80 & 1.67 & 0.4363 \\
\hline & & $\mathrm{A} / \mathrm{G}$ & 0.78 & 0.58 & 1.05 & 0.1057 \\
\hline & & $\mathrm{A} / \mathrm{A}$ & 1.00 & & & \\
\hline \multirow[t]{7}{*}{ rs3804099 } & dominant & $\mathrm{A} / \mathrm{A}$ & 1.00 & & & 0.0003 \\
\hline & & $\mathrm{T} / \mathrm{C}-\mathrm{C} / \mathrm{C}$ & 0.63 & 0.48 & 0.81 & \\
\hline & recessive & $\mathrm{T} / \mathrm{T}-\mathrm{T} / \mathrm{C}$ & 1.00 & & & 0.001 \\
\hline & & $\mathrm{C} / \mathrm{C}$ & 0.43 & 0.26 & 0.72 & \\
\hline & genotype & $\mathrm{C} / \mathrm{C}$ & 0.37 & 0.22 & 0.62 & 0.0002 \\
\hline & & $\mathrm{T} / \mathrm{C}$ & 0.69 & 0.53 & 0.90 & 0.006 \\
\hline & & $\mathrm{T} / \mathrm{T}$ & 1.00 & & & \\
\hline \multirow[t]{7}{*}{ rs3804100 } & dominant & $\mathrm{T} / \mathrm{T}$ & 1.00 & & & 0.0004 \\
\hline & & $\mathrm{T} / \mathrm{C}-\mathrm{C} / \mathrm{C}$ & 0.63 & 0.49 & 0.82 & \\
\hline & recessive & $\mathrm{T} / \mathrm{T}-\mathrm{T} / \mathrm{C}$ & 1.00 & & & 0.017 \\
\hline & & $\mathrm{C} / \mathrm{C}$ & 0.50 & 0.29 & 0.89 & \\
\hline & genotype & $\mathrm{C} / \mathrm{C}$ & 0.43 & 0.24 & 0.76 & 0.004 \\
\hline & & $\mathrm{T} / \mathrm{C}$ & 0.67 & 0.51 & 0.87 & 0.003 \\
\hline & & $\mathrm{T} / \mathrm{T}$ & 1.00 & & & \\
\hline \multirow[t]{7}{*}{ rs10759932 } & dominant & $\mathrm{T} / \mathrm{T}$ & 1.00 & & & 0.0007 \\
\hline & & $\mathrm{T} / \mathrm{C}-\mathrm{C} / \mathrm{C}$ & 1.57 & 1.21 & 2.04 & \\
\hline & recessive & $\mathrm{T} / \mathrm{T}-\mathrm{T} / \mathrm{C}$ & 1.00 & & & 0.173 \\
\hline & & $\mathrm{C} / \mathrm{C}$ & 1.30 & 0.89 & 1.88 & \\
\hline & genotype & $\mathrm{T} / \mathrm{T}$ & 1.59 & 1.07 & 2.37 & 0.021 \\
\hline & & $\mathrm{T} / \mathrm{C}$ & 1.56 & 1.18 & 2.07 & 0.002 \\
\hline & & $\mathrm{C} / \mathrm{C}$ & 1.00 & & & \\
\hline \multirow[t]{2}{*}{ rs11536878 } & dominant & $\mathrm{C} / \mathrm{C}$ & 1.00 & & & 0.257 \\
\hline & & $\mathrm{C} / \mathrm{A}-\mathrm{A} / \mathrm{A}$ & 0.84 & 0.62 & 1.14 & \\
\hline
\end{tabular}

(Continued) 


\begin{tabular}{|c|c|c|c|c|c|c|}
\hline SNP ID & $\begin{array}{c}\text { Model } \\
\text { recessive }\end{array}$ & $\frac{\text { Genotype }}{\mathrm{C} / \mathrm{C}-\mathrm{C} / \mathrm{A}}$ & $\frac{\text { OR }}{1.00}$ & \multicolumn{2}{|c|}{$95 \%$ CI } & $\frac{P \text { value }}{0.453}$ \\
\hline & & $\mathrm{A} / \mathrm{A}$ & 1.63 & 0.46 & 5.80 & \\
\hline & genotype & $\mathrm{A} / \mathrm{A}$ & 1.56 & 0.44 & 5.56 & 0.495 \\
\hline & & $\mathrm{C} / \mathrm{A}$ & 0.81 & 0.60 & 1.11 & 0.193 \\
\hline & & $\mathrm{C} / \mathrm{C}$ & 1.00 & & & \\
\hline \multirow[t]{7}{*}{ rs 12377632} & dominant & $\mathrm{C} / \mathrm{C}$ & 1.00 & & & 0.002 \\
\hline & & $\mathrm{C} / \mathrm{T}-\mathrm{T} / \mathrm{T}$ & 1.56 & 1.18 & 2.07 & \\
\hline & recessive & $\mathrm{C} / \mathrm{C}-\mathrm{C} / \mathrm{T}$ & & 1.00 & & 0.124 \\
\hline & & $\mathrm{T} / \mathrm{T}$ & 1.28 & 0.93 & 1.76 & \\
\hline & genotype & $\mathrm{T} / \mathrm{T}$ & 1.68 & 1.16 & 2.44 & 0.006 \\
\hline & & $\mathrm{C} / \mathrm{T}$ & 1.52 & 1.13 & 2.04 & 0.006 \\
\hline & & $\mathrm{C} / \mathrm{C}$ & 1.00 & & & \\
\hline \multirow[t]{7}{*}{ rs 11536889} & dominant & $\mathrm{G} / \mathrm{G}$ & 1.00 & & & $1.77 \mathrm{E}-06$ \\
\hline & & $\mathrm{G} / \mathrm{C}-\mathrm{C} / \mathrm{C}$ & 0.50 & 0.37 & 0.66 & \\
\hline & recessive & $\mathrm{G} / \mathrm{G}-\mathrm{G} / \mathrm{C}$ & 1.00 & & & 0.046 \\
\hline & & $\mathrm{C} / \mathrm{C}$ & 0.48 & 0.23 & 0.99 & \\
\hline & & $\mathrm{C} / \mathrm{C}$ & 0.40 & 0.19 & 0.83 & 0.0141 \\
\hline & & $\mathrm{G} / \mathrm{C}$ & 0.51 & 0.38 & 0.69 & $1.24 \mathrm{E}-05$ \\
\hline & & $\mathrm{G} / \mathrm{G}$ & 1.00 & & & \\
\hline \multirow[t]{7}{*}{ rs7873784 } & dominant & $\mathrm{G} / \mathrm{G}$ & 1.00 & & & 0.743 \\
\hline & & $\mathrm{G} / \mathrm{C}-\mathrm{C} / \mathrm{C}$ & 0.95 & 0.68 & 1.32 & \\
\hline & recessive & $\mathrm{G} / \mathrm{G}-\mathrm{G} / \mathrm{C}$ & 1.00 & & & 0.916 \\
\hline & & $\mathrm{C} / \mathrm{C}$ & 1.08 & 0.27 & 4.33 & \\
\hline & & $\mathrm{C} / \mathrm{C}$ & 1.07 & 0.27 & 4.30 & 0.928 \\
\hline & & $\mathrm{G} / \mathrm{C}$ & 0.94 & 0.67 & 1.32 & 0.722 \\
\hline & & $\mathrm{G} / \mathrm{G}$ & 1.00 & & & \\
\hline
\end{tabular}

SNP single nucleotide polymorphism, OR odds ratio, $95 \%$ CI $95 \%$ confidence interval.

$p \leq 0.05$ indicates statistical significance.

$p$ value were calculated using two-sided Chi-squared test.

the recessive model $(P<0.05)$, the $T / C-C / C$ genotype in the dominant model and the $\mathrm{C} / \mathrm{C}$ genotype in the recessive model of rs3804099 decreased 0.63-fold and 0.43-fold PTB risk $(P<0.05)$, the minor $\mathrm{C}$ allele of $\mathrm{rs} 3804100$ in the recessive model decreased 0.50 -fold risk and the $T / C-C / C$ genotype in the dominant model decreased 0.63 -fold $(P<0.05)$, the $T / C-C / C$ genotype in the dominant model of rs 10759932 and the $C / T-T / T$ genotype in the dominant model of rs 12377632 increased risk of TB based on analysis (The former $\mathrm{OR}=1.57$, $95 \% \mathrm{CI}=1.21-2.04, P=0.0008$. The latter $\mathrm{OR}=1.56,95 \%$ $\mathrm{CI}=1.18-2.07, P=0.002)$, the $G / C-C / C$ genotype in the dominant model and the $C / C$ genotype in the recessive model of rs 11536889 decreased 0.50 -fold and 0.48 -fold TB risk $(P<0.05)$.
Finally, a haplotype-based association study was performed to show the association betweenTLR2 haplotype and risk of PTB (Figure 1). We found that the candidate SNPs (rs3804099 and rs3804100) in the TLR2 gene showed strong linkage. We analysed the haplotype association with PTB, the results in Table 4.

\section{DISCUSSION}

The research results that is association analysis of pulmonary tuberculosis show there are two increased-risk SNPs (rs7696323, 1.32-foldrisk; rs12377632,1.30-fold risk) and three decreased-risk SNPs (rs3804099, 0.64-fold risk; rs3804100, 0.67-fold risk; rs11536889, 0.54-fold risk). 
Table 4: Haplotype frequencies and their associations with PTB risk

\begin{tabular}{lcccccc}
\hline Gene & SNPs & Haplotype & OR & \multicolumn{2}{c}{$\mathbf{9 5 \%}$ CI } & P \\
\hline TLR2 & rs3804099|rs3804100 & CC & 0.67 & 0.54 & 0.82 & 0.0002 \\
& & CT & 0.58 & 0.31 & 1.05 & 0.073 \\
& & TT & 1.56 & 1.27 & 1.91 & $2.11 \mathrm{E}-05$ \\
TLR4 & rs11536878|rs12377632 & AT & 0.88 & 0.66 & 1.17 & 0.3757 \\
& & CT & 1.45 & 1.19 & 1.76 & 0.0002 \\
& & CC & 0.76 & 0.63 & 0.91 & 0.004 \\
\hline
\end{tabular}

Previous PTB studies investigated the function of host genetic factors and immunoreactionin M. tuberculosis infection [11]. In humans, macrophages are the main host cells for the intracellular replication pathway of $M$. tuberculosis. Macrophages also serve as the antigenpresenting cells during the reactivation of lymphocytes, and they function as a vital killer of mycobacteria [12]. In vivo and in vitro studies show that $M$. tuberculosis infection causes apoptosis in monocytes and macrophages [13], and we previously found that apoptosis of these two cell types is a protective factor in human tuberculosis [14]. rs7696323 is located in the intron of the TLR2 gene located near 4q31.3 (precise position: 154605745) and rs11536889 is located in the 5'UTR of the TLR4 gene located near 9q33.1 (precise position: 120478131) has nothing to do with susceptibility of tuberculosis in Chinese Han children $[15,16]$. The results showed significantly different, the reason may be genetic heterogeneity affects the identification of genetic factors in the disease, because there is no strict phenotypic boundaries between different genotypes in etiology. Secondly, because the age and nationality of the two groups are different, meanwhile the Children's immune system development is not fully awake so that can't fully open the immune defense [17],thus the results are not comparable. The SNP ofrs 12377632 where is the promoter of the TLR4 gene located near 9q33.1 (precise position:120465144), Closely related to susceptibility to tuberculosis in our study. However, the correlation between the SNP and disease is rare [18-20]. Our study is the first to explore TLR2 and TLR4 polymorphisms and their association with PTB risk in a Tibetan Chinese population.

Our study was the first one to show that the variation of rs3804099 and rs3804100 in TLR2 influences the risk of tuberculosis (Figure 1). Compared with wild rs3804099 genotypes, the heterozygous mutation of type decreased TB risk, rs 3804100 is the same way. The allele of rs3804099 and rs3804100located in the Coding exon, but the two cSNPs were considered to be synonymous.

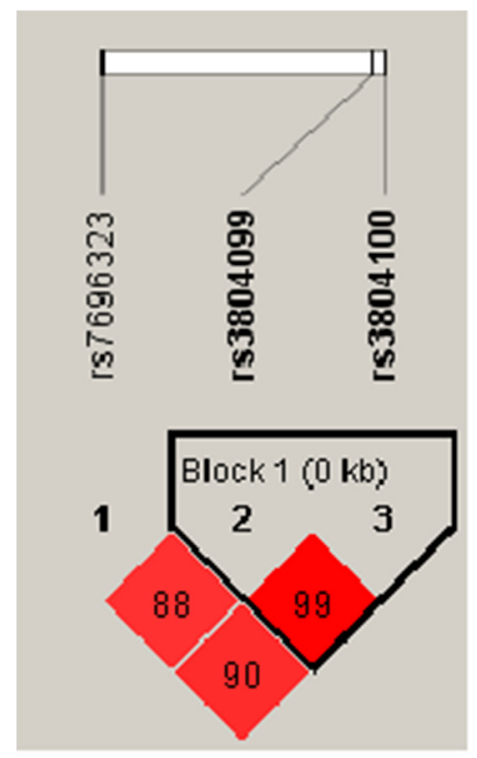

TLR2

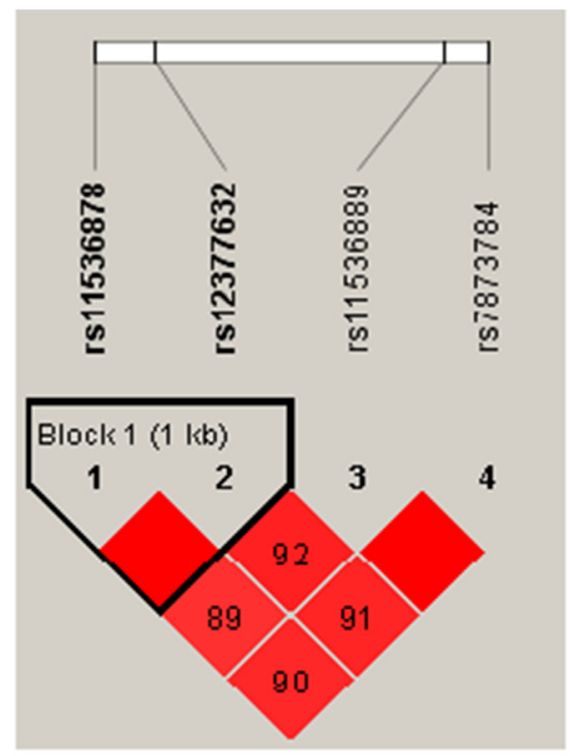

TLR4

Figure 1: Linkage disequilibrium plot of TLR2 and TLR4SNPs. 
It has long been assumed the change of the encoding sequence caused by SNP does not affect the amino acid sequence of the translated protein. However, in recent studies found new evidence that the synonymous SNPs changes in exons can directly alter mRNA transcription and splicing, or Affect the expression of remaining exons within the genes, or affect the stability of mRNA via cis factors and modulate mRNA structure [21-24]. Our results show, the mutation of TLR2 gene may play an important protective role in the incidence of tuberculosis, which should be further explored.

Before the beginning of the study, many experimental results confirm TLR2 and TLR4 are implicated in the regulation of a variety of inflammatory and immune disorders [25-27]. Thus, we planned to evaluate the nine SNPs come from above two genes correlation in TB patients, but there are a few questions: (1) If the SNP associated with MTB in the some crowd, so does it apply to all crowd? (2) If certain mutations is significative, mought Tuberculosis occur? Although we confirmed some SNP can increase or decrease TB risk, the concrete mechanism is still to be further studied.

In conclusion, some limitations should be noted in the present study. Firstly, we studied only the Tibetan people, and sample content is relatively small. Secondly, the association between genetic polymorphism and different subtypes of Mycobacterium Tuberculosis, was not distinguished. To date, different lineages of $\mathrm{M}$. tuberculosis strains cause the process of host detailed immune response is confirmed [28, 29]. This is very significant, different subtypes may match different SNPs [30]. But our study provides the first implied three the SNPs (rs7696323, rs3804099, rs3804100) come from TLR2 and two the SNPs (rs12377632, rs11536889) come from TLR4 indicated an association with MTB risk in the Tibetan Chinese population. But a basic molecular biologic are needed to confirm our findings in the future.

\section{MATERIALS AND METHODS}

\section{Ethics statement}

Our present study strictly observed the principles of the Declaration of Helsinki of the World Medical Association and was approved by the Ethics Committee of the Xi'an Jiaotong University Health Science center and the third Hospital of Tibet Autonomous Region. Informed consent forms were signed by all participants.

\section{Study participants}

Between October 2012 and September 2013, we selected 971 individuals Tibetan PTB patients were recruited from the third Hospital of Tibet Autonomous Region in Lhasa, China, including 467 PTB patients and 504 healthy controls. All PTB patients were ethnic
Tibetan and were newly diagnosed with consistent chest radiography and a positive sputum smear. Patients with human immunodeficiency virus (HIV), diabetes mellitus, or other tuberculosis diseases or who used immunosuppressive drugs were excluded. Individuals in the control group had no PTB history and no evidence of PTB in chest radiography or a positive sputum smear. We recruited subjects without consideration of age and gender.

\section{SNP selection}

We selected nine TLR2 and TLR4 SNPs with a minor allele frequency (MAF) above $5 \%$ in the HapMap Chinese Han Beijing population. We selected these SNPs on the basis of their allele frequencies, location, and disease relevance through public HapMap databases (w).

\section{Genotyping}

Genomic DNA was extracted from peripheral blood samples using a genomic DNA purification kit (GoldMag, Xi'an, China). We used spectrometry (DU530 UV/VIS spectrophotometer, Beckman Instruments, Fullerton, CA) to measure the DNA concentration. The primers for amplification and extension reactions were designed with SequenomMassARRAY Assay Design 3.0 Software (Sequenom, San Diego, CA) [31]. We used SequenomMassARRAY RS1000 to perform the SNP genotyping with the agreement of the manufacturer [31], and we used Sequenom Typer 4.0 software for data management and analysis $[31,32]$.

\section{Statistical analysis}

Microsoft Excel (Microsoft, Redmond, WA) and SPSS Statistics (version 17.0, SPSS, Chicago, IL) were used for statistical analyses. All $p$-values were two-tailed, and $p \leq 0.05$ was considered to be statistically significant. SNP genotype frequencies in the case and control groups were calculated by Chi-square tests, and the HardyWeinberg equilibrium (HWE) was used to check the genotype frequency of the control group. Unconditional logistic regression analysis was used to examine the odds ratios (ORs) and 95\% confidence intervals (CIs) in order to assess the association between SNPs and PTB [33]. Three models (dominant, recessive, log-additive) were used to test the association between SNPs and PTB [34]. Furthermore, Haploview (version 4.2, Broad Institute, Cambridge, MA) and SHEsis software were used for checking the linkage disequilibrium structure.

\section{Abbreviations}

Toll-like receptor: TLR; Pulmonary tuberculosis: PTB; Single nucleotide polymorphism: SNP; Odds ratio: 
OR; Confidence interval: CI; minor allele frequency: MAF; Hardy-Weinberg Equilibrium: HWE.

\section{Author contributions}

Xin Xue designed the experiments and wrote the manuscript. Dong Jiang, Mengdan Yan and Xikang Zhu performed the experiments. Yi Qiu and Tianbo Jin analyzed the data. Yonglie Chu conceived and designed the experiments.

\section{ACKNOWLEDGMENT}

We also like to thank the clinicians and hospital staff from the third Hospital of Tibet Autonomous Region, who contributed to the samples collection for this study.

\section{CONFLICTS OF INTEREST}

The authors have no conflicts of interest to report.

\section{REFERENCES}

1. NSW Health. Tuberculosis: factSheet. N S W Public Health Bull. 2000; 11: 156-7.

2. WHO. WHO global tuberculosis control report 2010. Summary. Cent Eur J Public Health. 2010; 18: 237.

3. Qu HQ, Fisher-Hoch SP, McCormick JB. Knowledge gaining by human genetic studies on tuberculosis susceptibility. J Hum Genet. 2011; 56: 177-82. https://doi. org/10.1038/jhg.2010.164.

4. Lykouras D, Sampsonas F, Kaparianos A, Karkoulias K, Tsoukalas G, Spiropoulos K. Human genes in TB infection: their role in immune response. Monaldi Arch Chest Dis. 2008; 69: 24-31.

5. Britton WJ, Fernando SL, Saunders BM, Sluyter R, Wiley JS. The genetic control of susceptibility to Mycobacterium tuberculosis. Novartis Found Symp. 2007; 281: 79-89; discussion -92, 208-9.

6. Comstock GW. Tuberculosis in twins: a re-analysis of the Prophit survey. Am Rev Respir Dis. 1978; 117: 621-4. https://doi.org/10.1164/arrd.1978.117.4.621.

7. Ates O, Dolek B, Dalyan L, Musellim B, Ongen G, TopalSarikaya A. The association between BsmI variant of vitamin D receptor gene and susceptibility to tuberculosis. Mol Biol Rep. 2011; 38: 2633-6. https://doi.org/10.1007/ s11033-010-0404-8.

8. Bonar A, Chmiela M, Rozalska B. [Level of mannosebinding lectin (MBL) in patients with tuberculosis]. [Article in Polish]. Pneumonol Alergol Pol. 2004; 72: 201-5.

9. Hu Q, Zhang M, He N, Liang G, Xu S, Wang Y, Mo F, Zhang H, Kang L, Jin T. Association of genetic polymorphisms with pulmonary tuberculosis in a Chinese
Tibetan population: a case-control study. Int J Clin Exp Pathol. 2016; 9: 267-74.

10. Sanchez D, Rojas M, Hernandez I, Radzioch D, Garcia LF, Barrera LF. Role of TLR2- and TLR4-mediated signaling in Mycobacterium tuberculosis-induced macrophage death. Cell Immunol. 2010; 260: 128-36. https://doi.org/10.1016/j. cellimm.2009.10.007.

11. Kato-Maeda M, Bifani PJ, Kreiswirth BN, Small PM. The nature and consequence of genetic variability within Mycobacterium tuberculosis. J Clin Invest. 2001; 107: 5337. https://doi.org/10.1172/JCI11426.

12. Chackerian AA, Perera TV, Behar SM. Gamma interferonproducing CD4+ T lymphocytes in the lung correlate with resistance to infection with Mycobacterium tuberculosis. Infect Immun. 2001; 69: 2666-74. https://doi.org/10.1128/ IAI.69.4.2666-2674.2001.

13. Keane J, Balcewicz-Sablinska MK, Remold HG, Chupp GL, Meek BB, Fenton MJ, Kornfeld H. Infection by Mycobacterium tuberculosis promotes human alveolar macrophage apoptosis. Infect Immun. 1997; 65: 298-304.

14. Mancino G, Placido R, Di Virgilio F. P2X7 receptors and apoptosis in tuberculosis infection. J Biol Regul Homeost Agents. 2001; 15: 286-93.

15. Xu F, Xie LP, Dong YK, Qi H, Sun L, Li JQ, Xiao J, Jiao WW, Shen C, Shen AD. Association between Polymorphisms of Toll like receptor 2 and the suseptibility to tuberculosis in Chinese Han children. Chin J Evid Based Pediatr. 2014; 9: 441-6. https://doi. org/10.3969/j.2014.06.008.

16. Jieqiong L, Lanpin X, Yakun D, Hui Q, Lin S, Weiwei J, Jin $X$, Fang X. Association between polymorphisms of Toll like receptor 4 and susceptibility to tuberculosis in Han Chinese children. J Shanxi Med Univ. 2014; 45: 1151-8. https://doi. org/10.13753 /j. 2014.12.010.

17. Basu Roy R, Whittaker E, Kampmann B. Current understanding of the immune response to tuberculosis in children. Curr Opin Infect Dis. 2012; 25: 250-7. https://doi. org/10.1097/QCO.0b013e3283529af9.

18. Umemura T, Katsuyama Y, Hamano H, Kitahara K, Takayama M, Arakura N, Kawa S, Tanaka E, Ota M. Association analysis of Toll-like receptor 4 polymorphisms with autoimmune pancreatitis. Hum Immunol. 2009; 70: 742-6. https://doi.org/10.1016/j.humimm.2009.05.009.

19. Ito M, Hanaoka M, Droma Y, Kobayashi N, Yasuo M, Kitaguchi Y, Horiuchi T, Ikegawa K, Katsuyama Y, Kubo K, Ota M. The association of Toll-like receptor 4 gene polymorphisms with the development of emphysema in Japanese subjects: a case control study. BMC Res Notes. 2012; 5: 36. https://doi.org/10.1186/1756-0500-5-36.

20. Bank S, Skytt Andersen P, Burisch J, Pedersen N, Roug S, Galsgaard J, Ydegaard Turino S, Broder Brodersen J, Rashid S, Kaiser Rasmussen B, Avlund S, Bastholm Olesen T, Jurgen Hoffmann H, et al. Polymorphisms in the inflammatory pathway genes TLR2, TLR4, TLR9, 
LY96, NFKBIA, NFKB1, TNFA, TNFRSF1A, IL6R, IL10, IL23R, PTPN22, and PPARG are associated with susceptibility of inflammatory bowel disease in a Danish cohort. PLoS One. 2014; 9: e98815. https://doi.org/10.1371/ journal.pone.0098815.

21. Fedetz M, Matesanz F, Caro-Maldonado A, Fernandez O, Tamayo JA, Guerrero M, Delgado C, Lopez-Guerrero JA, Alcina A. OAS1 gene haplotype confers susceptibility to multiple sclerosis. Tissue Antigens. 2006; 68: 446-9. https:// doi.org/10.1111/j.1399-0039.2006.00694.x.

22. Solis-Anez E, Delgado-Luengo W, Borjas-Fuentes L, Zabala W, Arraiz N, Pineda L, Portillo MG, GonzalezFerrer S, Chacin JA, Pena J, Montiel C, Morales A, Rojas de Atencio A, et al. [Molecular analysis of the GABRB3 gene in autistic patients: an exploratory study]. [Article in Spanish]. Invest Clin. 2007; 48: 225-42.

23. Hunt R, Sauna ZE, Ambudkar SV, Gottesman MM, KimchiSarfaty C. Silent (synonymous) SNPs: should we care about them? Methods Mol Biol. 2009; 578: 23-39. https://doi. org/10.1007/978-1-60327-411-1_2.

24. Shen LX, Basilion JP, Stanton VP Jr. Single-nucleotide polymorphisms can cause different structural folds of mRNA. Proc Natl Acad Sci U S A. 1999; 96: 7871-6.

25. Cook DN, Pisetsky DS, Schwartz DA. Toll-like receptors in the pathogenesis of human disease. Nat Immunol. 2004; 5: 975-9. https://doi.org/10.1038/ni1116.

26. Leung TF, Tang NL, Wong GW, Fok TF. CD14 and tolllike receptors: potential contribution of genetic factors and mechanisms to inflammation and allergy. Curr Drug Targets Inflamm Allergy. 2005; 4: 169-75.

27. Corr SC, O’Neill LA. Genetic variation in Toll-like receptor signalling and the risk of inflammatory and immune diseases. J Innate Immun. 2009; 1: 350-7. https://doi. org/10.1159/000200774.

28. Lopez B, Aguilar D, Orozco H, Burger M, Espitia C, Ritacco V, Barrera L, Kremer K, Hernandez-Pando R, Huygen K, van Soolingen D. A marked difference in pathogenesis and immune response induced by different Mycobacterium tuberculosis genotypes. Clin Exp Immunol. 2003; 133: 30-7.

29. Tanveer M, Hasan Z, Kanji A, Hussain R, Hasan R. Reduced TNF-alpha and IFN-gamma responses to Central Asian strain 1 and Beijing isolates of Mycobacterium tuberculosis in comparison with H37Rv strain. Trans R Soc Trop Med Hyg. 2009; 103: 581-7. https://doi.org/10.1016/j. trstmh.2009.03.014.

30. Varahram M, Farnia P, Nasiri MJ, Karahrudi MA, Dizagie MK, Velayati AA. Association of mycobacterium tuberculosis lineages with IFN-gamma and TNF-alpha gene polymorphisms among pulmonary tuberculosis patient. Mediterr J Hematol Infect Dis. 2014; 6: e2014015. https:// doi.org/10.4084/mjhid.2014.015.

31. Gabriel S, Ziaugra L, Tabbaa D. SNP genotyping using the Sequenom MassARRAY iPLEX platform. Curr Protoc Hum Genet. 2009; Chapter 2: Unit 2.12.

32. Thomas RK, Baker AC, Debiasi RM, Winckler W, Laframboise T, Lin WM, Wang M, Feng W, Zander T, Macconaill L. High-throughput oncogene mutation profiling in human cancer. Nat Genet. 2007; 39: 347-51.

33. Martin BJ, Altman DG. The odds ratio. BMJ. 2000; 320: 1468.

34. Solé X, Guinó E, Valls J, Iniesta R, Moreno V. SNPStats: a web tool for the analysis of association studies. Bioinformatics. 2006; 22: 1928-9. 